8. Rabiger, M. and Rabyher, M. (1999). Directing documentaries. Moscow: Institute for Advanced Studies of Television and Radio Broadcasters.

9. Sokolov, A.H. (2001). Installation: television, film, video. In part 3. Part 3. Moscow: 625.

10. Utylova, N.Y. (2004). Montazh : ucheb. posobye dlia studentov. Moscow: Aspekt Press.

(C) Петренко С. I., 2018

УДК 792.028.6=161.2-055.2:792 "19”

Погуца Наталя Миколаївна

аспірантка,

Київський національний

університет культури і мистецтв,

Київ, Україна

natik_matyash@ukr.net

\title{
ЕВОЛЮЦІЯ СЦЕНІЧНОГО ОБРАЗУ УКРАЇНКИ В ТЕАТРАЛЬНОМУ МИСТЕЦТВІ ПОЧАТКУ ХХ СТОЛІТТЯ
}

Мета статті - дослідити особливості еволюції сценічного образу українки в театральному мистецтві початку XX ст. Методи дослідження полягають у застосуванні мистецтвознавчого, а також історико-логічного методів. Зазначений методологічний підхід дозволяє розкрити головні причини, що зумовили динаміку еволюції сценічного образу українки в театральному мистецтві поч. XX ст. Реалізація поставленої мети передбачає вирішення таких завдань: охарактеризувати народний і модерністський напрямки в українській драматургії та театральному мистецтві початку XX ст.; проаналізувати еволюцію сценічного образу українки в контексті взаємодії народницьких і модерністських тенденцій; з'ясувати значення впливу обмеженого українського театрального простору на еволюцію сценічного образу українки. Наукова новизна. 3 позиції мистецтвознавства здійснено комплексний аналіз еволюції сценічного образу українки в театральному мистецтві на поч. XX ст. Вперше з'ясовано, що в українській драматургії поч. XX ст. чітко прослідковується два головних спрямування: народницьке й модерністське, які засвідчують про своєрідну амбівалентність національного театрального мистецтва означеного періоду. Висновки. Класичний український театр, зіпертий на потужний пласт традиційної культури, дбав про збереження духовних цінностей народу, а також сприяв європеїзації національного театрального мистецтва. На поч. XX ст. на сцені театру корифеїв, поряд із традиційним сценічним образом українки - героїні соціально-побутової драми та комедії, з'явилися героїні модерних п'єс Лесі Українки, В. Винниченка, О. Олеся, в образах яких розкривалися нові грані жіночого характеру. Еволюція 
сценічного образу українки відображала зміни в житті народу й ролі театру. Функціонування в обмеженому театральному просторі гальмувало природний розвиток українського театрального мистецтва, що позначилося на динаміці еволюції сценічного образу українки. Органічне поєднання в репертуарі класичного українського театру п’єс народницького та модерністського спрямувань дає автору статті підстави для обгрунтування висновку про своєрідну амбівалентність українського театрального мистецтва поч. XX ст. Підтверджено неправомірність протиставлення модерністського й народницького спрямувань у контексті українського театрального мистецтва поч. ХX ст.

Ключові слова: українське театральне мистецтво, народництво, модернізм, сценічний образ українки.

\section{Эволюция сценического образа украинки в театральном искусстве начала XX века}

Погуца Наталия Николаевна, аспирантка, Киевский национальный университет культуры и искусств, Киев, Украина.

Цель статьи - исследовать особенности эволюции сценического образа украинки в театральном искусстве начала XX в. Методы исследования заключаются в применении искусствоведческого, а также историкологического методов. Отмеченный методологический подход позволяет раскрыть главные причины, обусловившие динамику эволюции сценического образа украинки в театральном искусстве нач. XX в. Реализация поставленной цели предусматривает решение таких задач: охарактеризовать народническое и модернистское направления в украинской драматургии и театральном искусстве нач. XX в.; проанализировать эволюцию сценического образа украинки в контексте взаимодействия народнических и модернистских тенденций; выяснить значение влияния ограниченного украинского театрального пространства на эволюцию сценического образа украинки. Научная новизна. С позиции искусствоведения осуществлен комплексный ана лиз эволюции сценического образа украинки в театральном искусстве нач. XX в. Впервые выявлено, что в украинской драматургии нач. XX в. четко видны дв а главных направления: народный и модернистский. Выводы. Классический украинский театр, опиравшийся на мощный пласт традиционной культуры, заботился о сохранении духовных ценностей народа, а также способствовал европеизации национального театрального искусства. В начале XX в. на сцене театра корифеев, рядом с традиционным сценическим образом украинки героини социально-бытовой драмы и комедии, появились героини модерных пьес Леси Украинки, В. Винниченко, О. Олеся, в образах которых раскрывались новые грани женского характера. Эволюция сценического образа украинки отображала изменения в жизни народа и роли театра. Функционирование в ограниченном театральном пространстве тормозило естественное развитие украинского театрального искусства, которое отразилось на динамике эволюции сценического образа украинки. Органическое сочетание 
в репертуаре классического украинского театра пьес народнического и модернистского направлений дает автору статьи основания для обоснования вывода о своеобразной амбивалентности украинского театрального искусства начала XX в. Подтверждена неправомерность противопоставления модернистского и народнического направлений в контексте украинского театрального искусства нач. ХХ в.

Ключевые слова: украинское театральное искусство, народничество, модернизм, сценический образ украинки.

Pogutsa Natalia, postgraduate, Kyiv National University of Culture and Arts, Kyiv, Ukraine

Evolution of the stage image of a Ukrainian woman in the theatrical art of the beginning of the 20 th century

The purpose of the article is to study the evolution of the stage image of a Ukrainian woman in the theatrical art of the beginning of the 20th century. The research methodology consisted in the combination of the art-critical and historicallogical methods, which allowed for revealing the main reasons that preconditioned the dynamics of the evolution of the stage image of a Ukrainian woman in the theatrical art of the beginning of the 20th century. To fulfill the research purpose, the following tasks had to be completed: to characterize folk and modernist directions in the theatrical art of the beginning of the 20th century; to analyze the evolution of the stage image of a Ukrainian woman in the context of the interaction of folk and modernist tendencies; to reveal the importance of the influence of the limited Ukrainian theatrical space on the evolution of the stage image of a Ukrainian woman. The scientific novelty of the work lies in a complex analysis of the evolution of the stage image of a Ukrainian woman in the theatrical art of the beginning of the 20th century from the viewpoint of art criticism. It was discovered that the Ukrainian dramaturgy of the 20th century had two main and distinct directions - folk and modernist. Conclusions. Classical Ukrainian theater, resting upon a strong stratum of traditional culture, was concerned with preserving spiritual values of the people and also contributed to the Europeanization of national theatrical art. At the beginning of the 20th century, along with the traditional stage image of a Ukrainian female - the heroine of social-domestic drama and comedy a new heroine appeared on the stage of the theater of corypheus in modern plays by Lesia Ukrainka, V. Vynnychenko and O. Oles, whose images revealed new facets of the female character. The evolution of the stage image of a Ukrainian woman reflected the changes in the life of the nation and the role of theater. Functioning in the limited theatrical space hampered the natural development of Ukrainian theatrical art, which affected the dynamics of the evolution of the stage image of a Ukrainian woman. The organic combination of folk and modernist directions in the repertoire of the classical Ukrainian theater provided for substantiating the conclusion about the peculiar ambivalence of the Ukrainian theatrical art of the beginning of the 20th century. The baselessness of contrasting modernist and folk tendencies in the context of the Ukrainian theatrical art of the beginning of the 20th century was confirmed. 
Key words: Ukrainian theatrical art, populism, modernism, stage image of Ukrainian woman.

Вступ. На поч. XX ст. в українській драматургії та театральному мистецтві вирізняються два основних спрямування - модерністське й народницьке. У специфічних естетичних вимірах цих спрямувань відбувалася еволюція сценічного образу українки, зображуючи динаміку змін життя народу й відображення їх у мистецтві театру.

Матеріалом для статті були відомі театрознавчі праці I. Франка «Руський театр», С. Чарнецького «Театр», Лесі Українки (праця 1907 р. без заголовку, вміщена у виданні «Леся Українка. Про мистецтво»), а також дослідження О. В. Красильникової «Український театр: 1900-1941 рік» і присвячені драматургії розділи в колективній праці «Початок XX століття: загальні тенденції художньої еволюції», яка входить до складу п’ятого тому академічної «Історії української культури». І. Франко відзначає, що наявність у репертуарі галицького театру творів європейської драматургії ще не свідчила про високий рівень його художніх здобутків, як «ународовлення» українського театру в Російській імперії не було свідченням його відсталості і провінційності. С. Чарнецький наголошує, що під час нетривалого перебування в Галичині М. Садовський як режисер «зумів прогнати зі сцени старий, вичовганий шаблон, традицію бездушного наслідування, вказав практично галицькому акторові шлях і способи наблизити сцену до життєвої правди, природності та краси» [9, с. 615]. Про вплив М. Заньковецької, котра приїхала до Галичини разом із М. Садовським, С. Чарнецький пише: «Вона творила високомистецькі постаті... повні правди, сили i краси», що стали зразком для артисток галицького театру [9, с. 616]. Дорікаючи антрепренерам за відсутність у репертуарі театру творів європейської драматургії та п’єс 3 життя української інтелігенції, Леся Українка та ін. представники модерністського спрямування не завжди враховували фактор глядацької аудиторії, котру складали переважно представники низових верств суспільства [7]. Автори праці «Початок ХХ століття: загальні тенденції художньої еволюції» дають критичну оцінку сьогоденним спробам тенденційного трактування народницького спрямування в театральному мистецтві [1, с. 50-52]. Взаємодію традицій та новаторства у театральному мистецтві поч. XX ст. аналізує О. В. Красильникова в праці «Український театр: 1900-ті - 1941 рік», підкреслюючи, що створений М. Заньковецькою сценічний образ українки був знаковим для національної культури. О. Забужко в праці «Notre Damed'Ukraine: Українка в конфлікті міфологій» і Є. Кононенко в нарисі «Співоча душа України (Маруся Чурай. Леся Українка, Ліна Костенко)» аналізують особливості жіночих образів у драматургії Лесі Українки 3 позицій феміністичної критики. Діалектику взаємодії театрального мистецтва й авдиторії в обмеженому українському театральному просторі розкриває О. Мірошниченко у праці «Театр і публіка».

Виклад основного матеріалу. Характеризуючи особливості народницького й модерністського спрямувань в українській драматургії поч. 
XX ст., автори колективної праці «Початок XX століття: загальні тенденції художньої еволюції» відзначають: «За народництвом сьогодні міцно закріпилася наявність провінційності, колоніальності, яка лише гальмувала розвиток красного письменства, тоді як навіть безпорадні твори 3 «прогресивною» стилістикою майже автоматично опиняються в естетичному активі...» [1, с. 50]. Дослідники наголошують, що однозначне протиставлення модерністського й народницького спрямувань призводить до спрощеного уявлення про розвиток мистецтва означеного періоду, особливо театрального мистецтва. На відміну від мистецтва слова, театральне мистецтво - колективне, синкретичне. У ньому важлива не лише драматургічна основа, а й режисерське осмислення п'єси, акторське трактування ролей, сценічне оформлення спектаклю тощо. Драматургія соціально-побутового й соціально-психологічного характеру, яка належить до народницької традиції, відзначається зрілістю поетики й високою сценічністю, чого незрідка бракувало модерністським п'єсам і драматичним етюдам М. Вороного, О. Олеся, Г. Хоткевича, навіть драматичним творам Лесі Українки, частина з яких, до того ж, сприймається як «п’єси для читання», ніж для постановки. Відзначаючи до сьогодні спрощену рецепцію творів Лесі Українки «на масовому рівні», О. Кононенко стверджує: «...Драматургія Лесі Українки перебуває не лише в очікуванні театру, а й в очікуванні читача» [3, с. 244-245]. С. Кононенко солідаризується з тими дослідниками, які стверджують, що Леся Українка залишається осмисленою лише в площині Мавки, а не Кассандри чи Дон Жуана, звинувачуючи в цьому народницький та радянський підходи [3, с. 245]. Варто нагадати, що новаторські драми великої поетеси були вперше зіграні на сцені народницького театру корифеїв, і це були «Блакитна троянда» (1899) і «Камінний господар» (1914), а не «Лісова пісня». Свідченням того, що в театрі корифеїв розуміли раритетність «Камінного господаря» було залучення до постановки кращих сил театру: М. Садовський грав Командора, I. Мар'яненко - Дона Жуана, М. Малиш-Федорець - Донну Анну, сценографію вистави здійснив видатний театральний художник, вихованець Краківської академії мистецтв І. Бурячок [4, c. 560-561]. Отже, новий образ жінки, презентований у драматургії модерністського спрямування, стає сценічним образом для започаткованого класичного українського театру, який належить, насамперед, до народницької традиції.

Категорично протиставляючи жіночі образи із п’єс Лесі Українки «м'якотілості жіночого начала» у традиційних сценічних образах українки, Є. Кононенко стверджує: «М'ятежні героїні Лесі Українки є ніби уособленням гордого жіночого духу, героїчності, а не м'якотілості жіночого начала як такого, спростуванням міфічної концепції про Україну-покритку, повію, безталанну наймичку» [3, с. 246]. Зрозуміло, що, пишучи про «міфічну концепцію України», дослідниця має на увазі народницьку концепцію. Визнаючи часткову слушність цього протиставлення, все ж відзначимо, що сценічні образи покриток, безталанних i наймичок на сцені класичного українського театру навряд чи варто ототожнювати 3 «м'якотілістю жіночого 
начала» як такого: обираючи смерть замість безчестя, вони уособлювали жіночу гідність, незламність духу українки, а водночас - трагічну долю України, що відповідало історичним реаліям - становищу поневоленої нації. Якщо М. Заньковецьку називали символом української культури XX століття» [4, с. 558-559], то йшлося про втілення не лише «ідеї трагізму», а й краси, величі, творчого генія народу.

У сезоні 1911-1912 pp. у стаціонарному театрі М. Садовського в Києві 3'явилася нова афіша: дівчина-українка стояла на зораному полі обличчям до сонця, що сходило з-за пагорбів. Символічне значення цього образу зрозуміле: в умовах послаблення утисків театр кликав у майбутнє, позбавлене соціального й національного гніту. Образ молодої дівчини в національному вбранні втілював ідею чекання суспільних змін, а не ідею страждання.

Базуючись на класичному репертуарі й драматургії корифеїв, класичний театр, як уже зазначалося, приділяє увагу драматургії модерністського спрямування, зокрема, творам Лесі Українки й В. Винниченка. Еволюція сценічного образу українки в театрі М. Садовського відображала глибинні процеси суспільних змін. Драми Лесі Українки відкрили нові перспективи художнього осмислення образу жінки, адже авторка піднімала значущі для європейської культурної свідомості теми віднайдення ідентичності, любові й жертовності, творчої та релігійної свободи. Леся Українка переосмислює «вічні теми», сюжети, образи, розглядаючи їх з позицій української жінки представниці освіченої верстви суспільства. Надбанням української культури стали Кассандра (в однойменній драмі Лесі Українки), Донна Анна (у «Камінному господареві»), Міріам (у драматичній поемі «Одержима»). Новаторство Лесі Українки, на думку О. Забужко, полягає в гностикофеміністичній «переакцентації», перенесенні «центру ваги культурного космосу на от власне що “вічно-жіноче"» [2, с. 404]. О. Забужко, солідаризуючись із представницями сучасної феміністичної критики В. Агеєвою, С. Павличко та ін., наголошує в драматургії Лесі Українки протистояння між чоловічим і жіночим «первнями», стверджуючи, що власне жіночий «червень» поетеса визнає дужчим [2, с. 404-405].

У 1910 р. театр М. Садовського в Києві поставив п’єсу «Брехня» В. Винниченка - яскравого представника нового покоління українських драматургів європейського спрямування i рівня. Перед героїнями В. Винниченка постійно постають проблеми морального вибору й часто, не знаходячи виходу з критичних ситуацій, вибирають смерть (революціонеркапатріотка Софія - головна героїня п’єси «Між двох сил», котра поставлена перед вибором: зрадити родину чи ідеали революції). Конфлікт п’єси «Чорна Пантера і Білий Ведмідь» побудований на зіткненні двох стихій - батьківства й мистецтва. Коли суперечки між художником Корнієм i його дружиною Ритою, спричинені хворобою дитини, переходять у відверту ворожнечу, Рита вбиває чоловіка й себе. Поява на сцені українського театру героїнь В. Винниченка засвідчує еволюцію сценічного образу українки, котрий 
розкривається в нових обставинах, у форматі психологічної та інтелектуальної драми.

Драматургія Лесі Українки, В. Винниченка та ін. представників модерністського спрямування європеїзувала українське театральне мистецтво, традиційне «ународовлення» (I. Франко) яке було явищем неоднозначним. Обмежуючи репертуар українського театру лише п'єсами 3 народного життя, забороняючи постановку творів європейської та російської драматургії в українському перекладі, царський уряд, звичайно, прагнув загальмувати розвиток українського театрального мистецтва, занизити його рівень до провінційного, маргіналізувати. Однак мета не була досягнута. Як відзначав I. Франко, «...цензура мимо своєї волі і свідомості, штовхнула наш театр на Україні, а за ним і галицький, на ту дорогу, що найбільше відповідала потребам нашого часу» [8, с. 220]. Адже, на матеріалі драматургії народницької школи «...виховався цілий ряд першорядних артисток i артистів, таких, як Кропивницький, Садовський, а головне Заньковецька, що на неї заздрять українському театрові найкращі столичні театри Росії», - писав I. Франко [8, с. 199]. Видатний театрознавець відзначає «досить оригінальне i дивне явище»: на противагу українському театру, котрий «постав і виріс під обухом проскрипції і цензури в Росії», український театр «у конституційній.., “вільній” Галичині, в безпосередній близькості до Європи... щодо репертуару і гри артистів був швидше блідою копією, кволим наслідуванням третьорядних невеличких європейських театрів, ніж справжнім, хоч i дуже скромним українським народним театром» [8, с. 199].

Думки І. Франка про «європейськість» за ознакою наявності в репертуарі театру творів європейської драматургії, а за своєю суттю - наслідування третьорядних провінційних європейських театрів (цим відзначався український театр у Галичині на певному етапі свого розвитку) - i «ународовлення» театрального мистецтва у «материковій» Україні, що в умовах цензурних обмежень не призвело до його маргіналізації, а всупереч сподіванням імперської влади, спричинило творчий злет до рівня високих зразків європейського театрального мистецтва, не втрачають актуальності в наш час. «Народництво» театру корифеїв, що виявлялося, зокрема, у створенні М. Заньковецькою галереї досконалих сценічних образів українських селянок, не було синонімом «провінційності». «...І̆й не рукоплескали ні Париж, ні Лондон, ні Берлін - та Марію Заньковецьку величають актриси світової величини, - підкреслює А. Лемещенко. - Вона не грала в п’єсах європейських драматургів, бо в Російській імперії до 1905 р. існували заборони для українського театру на переклади творів зарубіжної драматургії. Та в інтерпретації Заньковецької образи п’єс М. Кропивницького, М. Старицького, I. Карпенка-Карого просякнуті мотивацією героїв Шекспіра і Шіллера, і Гете, і Золя, й Островського» [5, с. 259]. Працюючи над ролями звичайних українських селянок, М. Заньковецька спиралася і на здобутки європейської науки. На фотографіях, котрі готувалися для ілюстрацій петербурзького видання, праці Ч. Дарвіна «Выражение чувств у человека и животного», 
М. Заньковецька зафіксована у психологічних етюдах «Мати отримує звістку про смерть сина», «Скорбота», «Душа моя смертельно тужить», «Тихе божевілля», а також постає в образах античної богині смерті й масці Ісуса Христа [5, с. 262]. Відомо, що актриса вивчала поведінку божевільних жінок, відвідуючи психіатричну клініку. Отже, визначаючи своє амплуа як «інженюдраматік», прагнучи відтворити нюанси виявів трагізму в сценічних образах українок, М. Заньковецька зверталася до досліджень у галузі психології та психіатрії. Це сприяло досягненню вражаючої глибини й достовірності сценічних образів українських жінок у драмах I. Карпенка-Карого «Наймичка», М. Кропивницького «Глитай, або ж Павук» та ін.

Діючи в обмеженому театральному просторі, українське театральне мистецтво народницького спрямування подавало на сцені правдиву, яскраву картину народного життя. У сценічних образах, створених М. Заньковецькою, Л. Ліницькою, котра уславилась виконанням героїчних ролей, С. Зарницькою, котра втілювала на сцені ідеал вічної жіночності, мовби випромінювала тихе світло, а також Г. Борисоглібською, О. Полянською, задіяними в музичних виставах співачками О. Петляш, М. Литвиненко-Вольгемут, В. Старостинською та ін. розкривалися різні грані характеру українки, багатство ii душі, особливості світосприйняття, архетипи свідомості.

На нашу думку, можна говорити про певну амбівалентність українського театрального мистецтва поч. ХX ст. 3 одного боку, воно позначене фарбами консерватизму, традиційності, що пояснюється ідеєю збереження цінностей народної духовної культури, 3 іншого боку - відкрите до пошуку сприйнятливе до модерної стилістики нової драматургії. Виразно простежується процес трансформації сценічного образу українки - від безсмертної Наталки Полтавки й Харитини 3 «Наймички» I. Карпенка-Карого у виконанні представниць старшого покоління М. Заньковецької, Г. Борисоглібської, О. Полянської - до Донни Анни 3 «Камінного господаря» Лесі Українки у виконанні Л. Ліницької та героїнь В. Винниченка - представниць інтелігенції, революціонерок тощо.

Представляючи мистецтво бездержавного народу, український театр функціонував у обмеженому театральному просторі, його природний розвиток «стримувався отією неповноцінністю глядацької зали, відсутністю в ній багатьох культурно важливих верств суспільства» [6, с. 658]. Театр був зорієнтований переважно на представників низових верств суспільства, на демократичного масового глядача. Цю традицію, закладену засновниками, «не змогли пізніше подолати ані діяльність першого стаціонарного театру Миколи Садовського, ані представники нової модерної, орієнтованої на Захід хвилі драматургів (Леся Українка, В. Винниченко, О. Олесь та ін.), ані діяльність чи не найвидатнішого українського режисера Леся Курбаса, - відзначає О. Мірошниченко, додаючи: - Зрештою, трагедія Леся Курбаса - то не лише фатальне, неминуче зіткнення митця й тоталітарної системи, а й трагічна передчасність зустрічі його мистецтва 3 не підготовленим до його сприйняття українським глядачем» [6, с. 658]. Фактор глядацької аудиторії недооцінюють 
критики народницького спрямування, у звичних для демократичного глядача формах соціально-побутової драми й комедії, окрім високохудожніх творів першорядних драматургів, були написані й численні п’єси другорядних авторів, котрі користувалися популярністю у мандрівних театрів, що не подолали, на відміну від театру корифеїв, етап так званого фольклорно-етнографічного театру. «У таких формах реалізувалася, зокрема, ігрова концепція творчості, пов'язана 3 народним світобаченням, комічними ситуаціями, декоративністю й екзотикою етнографічного плану» [1, с. 50]. Сценічного втілення в широкій мережі провінційних українських театрів набували образи ліричних героїнь українських народних пісень («Така ії доля», «Закльована голубка, або за карі очі та чорні брови»). Еволюція образу українки на матеріалі широкого пласту масової культури, що розгортався в драматургії забутих авторів і на сценах провінційних мандрівних театрів, може зацікавити дослідників масової української культури й потребує висвітлення в спеціальних працях.

Наукова новизна. 3 позиції мистецтвознавства здійснено комплексний аналіз еволюції сценічного образу українки в театральному мистецтві на поч. XX ст. Вперше з'ясовано, що в українській драматургії поч. XX ст. чітко прослідковується два головних спрямування: народницьке й модерністське, які засвідчують про своєрідну амбівалентність національного театрального мистецтва означеного періоду.

Висновки. В українській драматургії поч. ХX ст. виокремилися два головних спрямування: народницьке й модерністське. Твори обох їх були представлені в репертуарі театру корифеїв, що свідчить про своєрідну амбівалентність національного театрального мистецтва означеного періоду й неправомірність протиставлення традиційності та європейськості у вимірах театрального процесу.

Поряд із традиційним сценічним образом українки - героїні соціальнопобутової драми та комедії на сцені українського класичного театру з'явилися героїні модерних філософських та інтелектуальних драм Лесі Українки, В. Винниченка, в образах яких розкривалися нові грані жіночого характеру. Український театр, зіпертий на потужний пласт традиційної культури, дбав про збереження духовних цінностей народу, а також сприяв європеїзації національного театрального мистецтва.

Еволюція сценічного образу українки відбивала зміни в житті народу й театру. Презентуючи мистецтво бездержавного народу, український театр поч. XX ст. функціонував у обмеженому театральному просторі, що гальмувало його природний розвиток i позначилося на еволюції сценічного образу українки.

\section{Список використаних джерел}

1. Агеєва В. П. Початок XX століття: загальні тенденції художньої еволюції / В. П. Агеєва, І. П. Бетко, Т. І. [та ін.] // Історія української культури. У 5 т. Т. 5. Кн. 2. - Київ, 2011. - С. 7-62. 
2. Забужко O. Notre Dame d'Ukraine: українка в конфлікті міфологій / О. Забужко. - 3-є вид. - Київ: Факт, 2007. - 640 с.

3. Кононенко Є. Співоча душа України (Маруся Чурай, Леся Українка, Ліна Костенко) / Є. Кононенко // Герої та знаменитості в українській культурі. Київ, 1999. - С. 234-248.

4. Красильникова О. В. Український театр: 1900-ті - 1941 рік / О. В. Красильникова // Історія української культури. У 5 т. Т. 5. Кн. 2. - Київ, 2011. - C. 553-596.

5. Лемещенко А. Марія Заньковецька - легенда українського театру / А. Лемещенко // Українки в історії. - Київ, 2004. - С. 259-264.

6. Мірошниченко О. Театр і публіка / О. Мірошниченко // Нариси української популярної культури. - Київ, 1998. - С. 655-666.

7. Українка Л. Про мистецтво / Л. Українка. - Київ: Мистецтво, 1966. 299 c. .

8. Франко I. Руський театр / I. Франко // Твори. У 20 т. Т. 16. - Київ, 1955. - С. 194-208.

9. Чарнецький С. Театр / С. Чарнецький // Історія української культури. Київ, 1994. - С. 593-620.

\section{References}

1. Aheieva, V. The beginning of the 20th century: general tendencies of artistic evolution. Istoriia ukrainskoi kultury. U 5 t. T. 5. Kn. 2. [History of Ukrainian Culture], In vols. 5. Vol. 5. Book. 2., pp. 7-62.

2. Zabuzhko, O. (2007). Notre Dame d'Ukraine: a Ukrainian woman in the conflict of mythologies. Kyiv: Fakt.

3. Kononenko, Ye. (1999). Singing soul of Ukraine (Marusya Churai, Lesya Ukrainka, Lina Kostenko). Heroi ta znamenytosti $v$ ukrainskii kulturi [Heroes and celebrities in Ukrainian culture],pp. 234-248.

4. Krasylnykova, O. (2011). Ukrainian Theater: 1900s - 1941. Istoriia ukrainskoi kultury. U 5 t. T. 5. Kn. 2. [History of Ukrainian Culture], In vols.5. vol. 5. Book. 2., pp. 553-596.

5. Lemeshchenko, A. (2004). Maria Zankovetska - the legend of Ukrainian theater. Ukrainky v istorii [Ukrainian women in history], pp. 259-264.

6. Miroshnychenko, O. (1998). Theater and public. Narysy ukrainskoi populiarnoi kultury [Essays on Ukrainian popular culture], pp.655-666.

7. Ukrainka, L. (1966). On art. Kyiv: Mystetstvo.

8. Franko, I. (1995). Russian Theater. Tvory. U 20 t. T. 16. [Writings], in 20 vols. Vol. 16, pp. 194-208.

9. Charnetskyi, S. (1994). Theater. Istoriia ukrainskoi kultury [History of Ukrainian Culture], pp.593-620.

(C) Погуu̧a H. М., 2018 